УДК 336.02

\title{
ФІНАНСОВО-ПОДАТКОВИЙ АСПЕКТ ГОСПОДАРСЬКОї ДІЯЛЬНОСТІ ЦИФРОВИХ КОРПОРАЦІЙ НА МІЖНАРОДНИХ РИНКАХ
}

\section{FINANCIAL AND TAX ASPECTS OF DIGITAL CORPORATIONS' BUSINESS ACTIVITY IN INTERNATIONAL MARKETS}

\author{
Благодир Лілія Миколаївна \\ кандидат економічних наук, доцент, \\ Вінницький національний технічний університет \\ ORCID: https://orcid.org/0000-0003-1685-3457 \\ Філатова Любов Сергіївна \\ кандидат економічних наук, старший викладач, \\ Вінницький національний технічний університет \\ ORCID: https://orcid.org/0000-0001-7713-307x
}

\author{
Blagodyr Liliya, Filatova Lyubov \\ Vinnytsya National Technical University
}

\begin{abstract}
У статті досліджується вплив цифррової трансформації на фрінанси, оподаткування і бізнес-моделі сучасних технологічних компаній. Визначено технології, що впливають на традиційні способи ведення господарської діяльності, а також сприяють появі нових бізнес-моделей. Здійснено порівняння традиційної і цифрової бізнес-моделей за такими ключовими критеріями, як активи, наявність і характер ефекту масштабу, створення цінності, темпи росту, домінуюче джерело залучення капіталу, парадокс прибутковості, рівень транзакційних витрат, наявність територіальних обмежень для взаємодії, інноваційна активність, драйвер зростання вартості бізнесу. Виявлено, що механізм функціонування і розвитку цифрових компаній на сьогодні не вкладається в традиційну фінансово-економічну парадигму, коли прибутковість компанії є ключовим показником ефективності діяльності і драйвером зростання її вартості. Проаналізовано рівень податкового навантаження на публічні акціонерні компанії з різних секторів економіки США за 2019 р. шляхом порівняння ефективних ставок податку на прибуток і федеральної номінальної ставки. Виявлено, що для промислових компаній ефективні податкові ставки є вищими, ніж для цифрових технологічних компаній. Доведено, що застосування нині діючих міжнародних підходів до прямого оподаткування на основі джерела прибутку або місцезнаходження компанії в умовах віртуалізації бізнесу має певні обмеження.
\end{abstract}

Ключові слова: фрінанси, податок на прибуток, ефективна податкова ставка, цифрова економіка, публічна акціонерна компанія, цифрова корпорація, парадокс прибутковості, лінійна бізнес-модель, мережева бізнесмодель, ринкова капіталізація, ефективність функціонування компанії.

В статье исследуется влияние цифровой трансформации на фринансы, налогообложение и бизнесмодели современных технологических компаний. Определены технологии, влияющие на традиционные способы ведения хозяйственной деятельности, а также способствуют появлению новых бизнес-моделей. Проведено сравнение традиционной и цифровой бизнес-моделей по ключевым критериям, таким как активы, наличие и характер эффеекта масштаба, создание ценности, темпы роста, доминирующее источник привлечения капитала, парадокс прибільности, уровень транзакционных издержек, наличие территориальных ограничений для взаимодействия, инновационная активность и т.д. Выявлено, что механизм функционирования и развития цифровых компаний сегодня не укладывается в традиционную фринансово-экономическую парадигму, когда прибыльность компании является ключевым показателем эффрективности деятельности и драйвером роста ее стоимости. Проанализирован уровень налоговой нагрузки на публичные акционерные компании из различных секторов экономики США за 2019 путем сравнения эффективных ставок налога на прибыль и федеральной номинальной ставки. Выявлено, что для промышленных компаний эффективные налоговые ставки выше, чем для цифровых технологических компаний. Доказано, что в условиях виртуализации бизнеса применение ныне действующих между- 
народных подходов к прямому налогообложения на основе источника прибыли или местонахождения компании имеет определенные ограничения.

Ключевые слова: фринансы, налог на прибыль, эфффективная налоговая ставка, цифровая экономика, публичная акционерная компания, цифровая корпорация, парадокс прибыльности, линейная бизнес-модель, сетевая бизнес-модель, рыночная капитализация, эффективность функционирования компании.

The paper deals with the digital transformation challenges of the companies' business models. There had been determined the modern digital technologies that influence the traditional ways of economic activities, favoring thus the emerging of the new business models. Linear and network business models had been compared using such key criteria as assets, availability and nature of the scale effect, value creation, growth rate, dominant source of capital attraction, profitability paradox, level of transactional costs, presence of territorial restrictions for interaction, innovation activity, business value growing driver. It had been determined that the functioning and developing mechanism of digital companies today does not fit into the traditional financial and economic paradigm, when the company's profitability is a key indicator of efficiency and driver for its value growing. The phenomena of "profitability paradox" and "capitalization gap" had been determined on the example of joint-stock companies in various sectors of the US economy. There had been analyzed the level of tax burden on joint stock companies in various sectors of the US economy in 2019 by comparing the effective income tax rates with the federal nominal rate. It was found that the effective tax rates for industrial companies are higher than for digital technology companies. This proves the relevance of the discussion as for the principles of taxation in the context of digital transformation of the economy, in particular, the principle of justice. It had been proved that the current international approaches to the direct taxation that is based on the revenue or on the location of the company under the conditions of business virtualization have certain restrictions for their application. In particular, the question arises about the "significant economic presence" and the search for its criteria. The researches show that the taxation of the foreign company requires the availability of the national customer base; the volume of the digital content created by national users; invoicing in national currency or using the national payment system; availability and maintenance of the website in the language of the country, delivery of goods directly to the customers or provision of accompanying services; marketing activities to attract customers.

Keywords: finance, income tax, effective tax rate, digital economy, joint stock company, digital corporation, profitability paradox, linear business model, network business model, market capitalization, company efficiency.

Постановка проблеми. Цифрові платформи, пули прав інтелектуальної власності, Big Data, цифрові алгоритми, технології адресного маркетингу, з одного боку і трансформація мислення, психології і сприйняття споживачів - 3 іншого створюють принципово нові умови на ринках. Зазнають змін підходи до монетизації доходів компаній, оскільки їх господарська діяльність будується тепер не тільки на матеріальних аспектах обороту товарів і послуг, а й на залученні і концентрації уваги користувачів. Цифрові технологічні гіганти вже не вивчають, а фрормують смаки і переваги споживачів. Інформаційно-комунікаційні технології дозволяють компаніям взаємодіяти 3 клієнтами на ринках віддалено, або через обмежену фрізичну присутність в окремих юрисдикціях. Це породжує низку проблем у сорері фрінансів і прямого оподаткування корпорацій, зокрема питання розподілу оподатковуваного доходу між різними юрисдикціями загострює податкову конкуренцію між країнами.

Аналіз останніх досліджень і публікацій. В площині нашого дослідження привертають до себе увагу праці науковців Т. Кощук, О. Вієцької, В. Говіндараджана, Р. Бухта, Р. Хікса, Г. Бауера, М. Купер, А. Туріна, Дж. Паркера,
М. ван Альстіна, Р. Шнайдера, М. Сігекі, О. Йосуке та ін., а також дослідження таких міжнародних інституцій як Організація економічного співробітництва і розвитку (далі ОЕСР), Світовий банк, Європейська комісія тощо.

Отже, як показав аналіз літератури, увага наукової спільноти і міжнародних організацій зосереджена на таких напрямках досліджень:

- оцінка масштабів ухилення корпорацій від сплати податків і податкова конкуренція між державами [1-3];

- вплив відмінностей податкових систем різних країн на поведінку мультинаціональних корпорацій [3-5];

- проблеми корпоративного оподаткування міжнародного бізнесу [6; 7];

- аналіз впливу цифррових технологій на бізнес-моделі корпорацій і фрінансовий облік їх діяльності [1; 7-12];

- забезпечення збалансованості державного бюджету і справедливість оподаткування корпорацій [11; 12];

- пошук консенсуса на міжнародному i національному рівнях у галузі оподаткування бізнес-моделей 3 високим рівнем цифровізації $[1 ; 2 ; 11 ; 12]$.

Виділення невирішених раніше частин загальної проблеми. Разом 3 тим, 
попри багатогранність і фрундаментальність зазначених праць вважаємо, що проблематика функціонування цифрових компаній потребує подальших досліджень 3 огляду на динамічність і непередбачуваність бізнессередовища, загрозу монополізації ринків, політичний тиск 3 боку циоррових технологічних гігантів на уряди країн в галузі податкового законодавства.

Формулювання цілей статті (постановка завдання). Мета нашого дослідження полягає у виявленні особливостей господарської діяльності сучасних цисррових компаній, які впливають в міжнародному контексті на їх корпоративні фрінанси і оподаткування.

Виклад основного матеріалу дослідження. Цифрова трансорормація змінює бізнес-процеси, бізнес-моделі і економічні відносини, як на рівні компаній, так і економіки в цілому. В основі цих змін лежать новітні технології (рис. 1), що фрормують обриси цифррової економіки як специсрічної системи соціально-економічних відносин.

Зазначені технології сприяють появі нових фрорм господарювання, зниженню транзакційних витрат ведення бізнесу, підвищенню ефрективності фрункціонування компаній.

Разом з тим, в ході циоррової трансорормації економіки, як зазначається [5] виникає ряд протиріч:

- ріст продуктивності внаслідок розвитку цифрових технологій посилює нерівність роз- поділу. Наприклад, автоматизація на основі використання роботів і штучного інтелекту скорочує число задач, у виконанні яких перевагу мають люди-працівники, а перетік капіталу між секторами економіки знижує рівень оплати праці;

- концентрація даних, технологій і кадрів, 3 одного боку, стимулює інновації, а з іншого підвищує ризики монополізації, обмежує різноманіття досліджень і розробок, актуалізує питання в галузі оподаткування цифррових технологічних гігантів;

- консолідація даних, з одного боку, дозволяє підвищити якість послуг, а з іншого - загострює ризики, пов'язані із захистом приватності і забезпеченням безпеки користувачів.

На думку М. Пасквінеллі [13], в бізнесмоделях циоррової економіки відбувся перехід від прибутку до ренти. Прибуток - дохід, який отримують в результаті продажу товарів, в той час як рента - дохід від монополістичної експлуатації простору. У феодальні часи джерелом ренти була експлуатація землі, оброблюваної залежними від фреодала селянами. Також, рента $є$ елементом моделі FIRE ${ }^{1}$-економіки, характерної для великих мегаполісів або нафтових олігархій, заснованих на експлуатації багатих на природні ресурси територій. Натомість в епоху Інтернету джерелом ренти стають віртуальні простори, які «обробляються» культурними виробниками, або проз'юмерами².

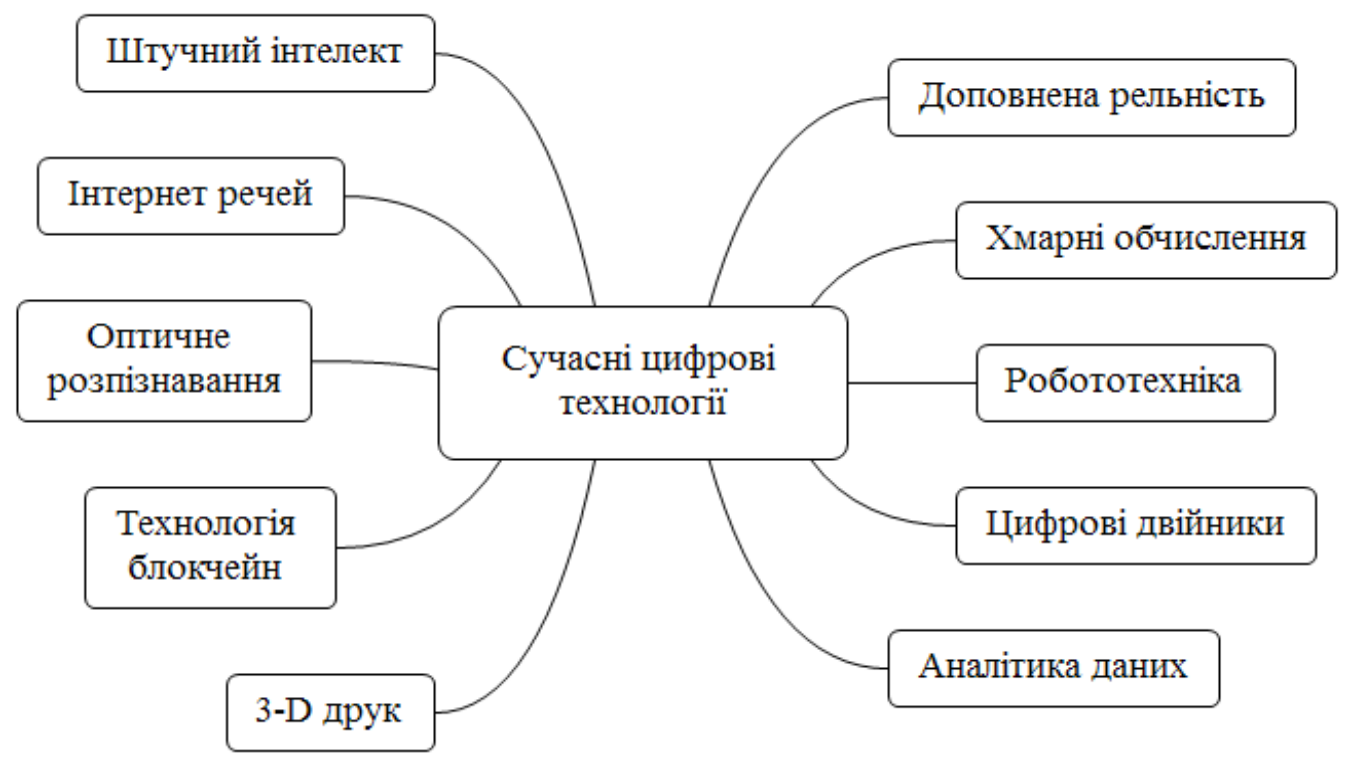

Рис. 1. Драйвери цифрової трансформації: технологічний аспект Джерело: побудовано автором на основі [12; 14]

\footnotetext{
${ }^{1}$ Акронім від англ. finance, insurance, real estate - фрінанси, страхування, нерухомість

2 Prosumer - від англ. producer (виробник) і consumer (споживач)
} 
Це означає, що участь користувача $\epsilon$ критично важливим фрактором цінності для певних видів цифррового бізнесу. Оскільки генеровані користувачем дані $€$ специсрічним економічним ресурсом, необхідним для створення вартості і отримання вигод. Більше того, здатність компанії контролювати дані має стратегічно важливе значення, адже це дозволяє перетворити їх на «цифрровий капітал» [7], який створює конкурентні переваги для посилення впливу компанії на ринку.

Загалом ОЕСР у своєму звіті [12, с. 24] наводить характеристики цифррового бізнесу, які вирізняють його з поміж інших способів ведення господарської діяльності і впливають на корпоративні фрінанси і оподаткування:

- міжюрисдикційне узгодження (масштаб діяльності без фрізичної присутності). Цифрровізація дозволяє компаніям розміщувати послідовні етапи своїх виробничих процесів у різних країнах, і водночас отримувати доступ до більшої кількості клієнтів по всьому світу. Компанія може брати участь у економічному житті певної держави без фрізичної присутності на ринку споживача, тобто досягати локального операційного масштабу без локальної присутності. Це означає, що цифррові компанії отримують доступ до зарубіжних ринків без виникнення зв'язку в юрисдикції відповідно до традиційних принципів (компанія може працювати в юрисдикції, не маючи фріліалу чи постійного представництва через недостатню фрізичну присутність для їх створення);

- опора на нематеріальні активи, включаючи інтелектуальну власність. Цифрові компанії інвестують значні кошти у нематеріальні активи, особливо інтелектуальну власність. Інтенсивне використання таких активів (наприклад, програмного забезпечення та алгоритмів, що підтримують функціонування цифррових платорорм, екосистем тощо) $€$ ключовим для цифрових компаній на основі цифррової мережевої бізнес-моделі;

- дані користувачів та створений ними контент $€$ важливим компонентом в бізнес-моделях цифррових компаній. Користь від аналізу даних зростає зі збільшенням кількості зібраної інформації, пов'язаної з конкретним користувачем чи замовником. Наприклад, користувачі відіграють важливу роль для соціальних мереж, маркет-плейсів, де без їх участі не виникає мережевих ефректів і не створюється унікальний цифровий контент;

- створення цінності в цифрових бізнесмоделях 3 т.з. місця створення та особис- тості творця. Міжюрисдикційний масштаб без фрізичної присутності та використання переважно нематеріальних активів $€$ ключовими фракторами для створення цінності цифрровими компаніями.

В табл. 1 наведено порівняння традиційної бізнес-моделі на основі активів і циорової бізнес-моделі. Бізнес-модель розглядається як логіка створення цінності для споживача і монетизації доходу для компанії.

Як бачимо, механізми фрункціонування бізнес-моделі на основі активів і цифрової бізнес-моделі різняться за структурою активів і витрат, фракторами фрормування цінності, джерелами залучення фрінансування тощо. Зокрема, бізнес-модель на основі матеріальних активів будується навколо лінійного ланцюга створення вартості. Цифрова бізнесмодель ґрунтується на цифррових продуктах і послугах, які рекламуються, просуваються і розподіляються через цифрові канали, такі як багатосторонні цифрові платформи і мобільні застосунки.

Цифрова бізнес-модель, як зазначається [10], може бути лінійною і мережевою. В рамках лінійної цифрової бізнес-моделі створюється продукт, який продається споживачам (наприклад, компанія Netflix як стрімінговий сервіс продає підписку на пакети своїх послуг; Microsoft надає програмне забезпечення як послугу тощо). Мережева циоррова бізнес-модель не передбачає створення нового продукту і пов'язана здебільшого із наданням посередницьких послуг різним групам учасників багатосторонніх цифррових платорорм (наприклад, соціальні мережі Facebook, Instagram, маркет-плейси Amazon, Etsy, Alibaba тощо). Загалом, поділ бізнес-моделей сучасних технологічних компаній на лінійні і мережеві $є$ досить умовним 3 огляду на те, що вони постійно перефрорматовують свою діяльність так, аби максимально використовувати переваги концепції SMAC (розвиток у напрямку соціальних, мобільних, аналітичних і хмарних технологій тощо).

Слід зазначити, що класифрікація цифрових бізнес-моделей на основі різних критеріїв, зокрема підходів до монетизації, сторін, задіяних у бізнесі, $є$ важливим науковим завданням.

Промислові компанії-старожили 3 бізнесмоделями на основі матеріальних активів тривалий час домінували на різних ринках, але на сьогодні існує розрив між обсягами ринкової капіталізації промислових і цифрових компаній (рис. 2). 
Таблиця 1

Порівняльна характеристика бізнес-моделей

\begin{tabular}{|c|c|c|}
\hline Ознака & $\begin{array}{c}\text { Бізнес-модель на основі } \\
\text { матеріальних активів }\end{array}$ & Цисррова бізнес-модель \\
\hline Активи & Домінують матеріальні & Домінують нематеріальні \\
\hline Ефрект масштабу & $\begin{array}{l}\text { Обмежений, після досягнення } \\
\text { критичної точки граничні витрати } \\
\text { зростають }\end{array}$ & $\begin{array}{l}\text { Не обмежений; граничні витрати } \\
\text { наближаються до нуля }\end{array}$ \\
\hline Створення цінності & $\begin{array}{l}\text { Цінність створюється послідовно } \\
\text { за рахунок контролю витрат } \\
\text { на кожній послідовній стадії } \\
\text { виробництва. Процес є } \\
\text { фондомістким. } \\
\end{array}$ & $\begin{array}{l}\text { Цінність створюється децентра- } \\
\text { лізовано в процесі виникнення } \\
\text { зв'язків (мережевого ринку) між } \\
\text { споживачами і виробниками. } \\
\text { Процес не є фрондомістким. }\end{array}$ \\
\hline Темп росту & Повільний & $\begin{array}{l}\text { Швидке експоненціальне } \\
\text { зростання }\end{array}$ \\
\hline $\begin{array}{l}\text { Джерело зć } \\
\text { капіталу }\end{array}$ & іасні джерела & $\begin{array}{l}\text { залучені джерела } \\
\text { зняя }\end{array}$ \\
\hline Парадокс прибутковості & Відсутній & $\begin{array}{l}\text { На фроні хронічної збитковості } \\
\text { компанії зростає ії капіталізація }\end{array}$ \\
\hline Транзакційні витрати & Середні, високі & Низькі \\
\hline $\begin{array}{l}\text { Обмеження для } \\
\text { взаємодії }\end{array}$ & Територіальні, міжнародні & \begin{tabular}{|l} 
Відсутність будь-яких \\
територіальних обмежень
\end{tabular} \\
\hline Інноваційна активність & Середня реактивна & $\begin{array}{l}\text { Висока проактивна; проривні } \\
\text { інновації фрормують нові ринки }\end{array}$ \\
\hline $\begin{array}{l}\text { Драйвер зростання } \\
\text { вартості бізнесу }\end{array}$ & $\begin{array}{l}\text { Грошові потоки, що генеруються } \\
\text { активами }\end{array}$ & Мережевий ефект \\
\hline Ринок & Фізичний простір & Віртуальний і фрізичний простір \\
\hline
\end{tabular}

Джерело: узагальнено авторами на основі [10, с. 4; 11]

Бульбашкова діаграма (рис. 2) показує, що ані «вік» компанії, ані розмір ії чистого прибутку не $є$ чинником високої капіталізації на фрондовому ринку. Станом на травень 2020 р. шість $з$ десяти компаній-лідерів за капіталізацією були циорровими високотехнологічними корпораціями (Microsoft, Apple, Amazon, Alphabet, Facebook, Alibaba) Механізм фрункціонування і розвитку цисррових компаній на сьогодні не вкладається в традиційну фрінансово-економічну парадигму, коли прибутковість компанії $€$ ключовим показником ефрективності діяльності і драйвером зростання іiї вартості. Як видно з діаграми, на фрондовому ринку існує такий френомен як «парадокс прибутковості», тобто компанія може бути не надто прибутковою або навіть збитковою, але ії капіталізація $€$ значною.

Згідно 3 [8; 15] це явище може бути зумовлене невідповідністю норм бухгалтерського фрінансового обліку специфріці господарської діяльності цифрових компаній. Зокрема, джерелом створення вартості в традиційних лінійних бізнес-моделях $є$ матеріальні активи, натомість в цифррових бізнес-моделях провідну роль для створення вартості відіграють нематеріальні активи, зокрема компетенції працівників, цифррові технології, мережеві ефректи, які поки що не знаходять свого відображення у фрінансовій звітності.

Поряд з питанням про відповідність діючих норм бухгалтерського фрінансового обліку i звітності характеристикам сучасних цифрових бізнес-моделей і джерелам створення вартості актуалізується проблема прямого оподаткування результатів діяльності цифрових компаній.

Для порівняння податкового навантаження на публічні корпорації з різних секторів економіки США визначимо ефективні податкові ставки податку на прибуток за даними їх фрінансової звітності (рис. 3). Прибуток акціонерних публічних компаній оподатковується на фредеральному рівні, рівні штату, а також місцевому рівні. 32018 р. після податкової реформи федеральна ставка податку на прибуток в США становить 21\%. Ставки корпоративного податку на рівні штату зазвичай варіюються від 1\% до 12\%. У деяких штатах податок на прибуток не стягується.

Отже, як видно з діаграми компанії технологічного сектору США (Apple, Microsoft, Alphabet, Cisco, IBM), а також компанії сектору телекомунікацій (AT\&T, Verizone) за 2019 р. спла- 


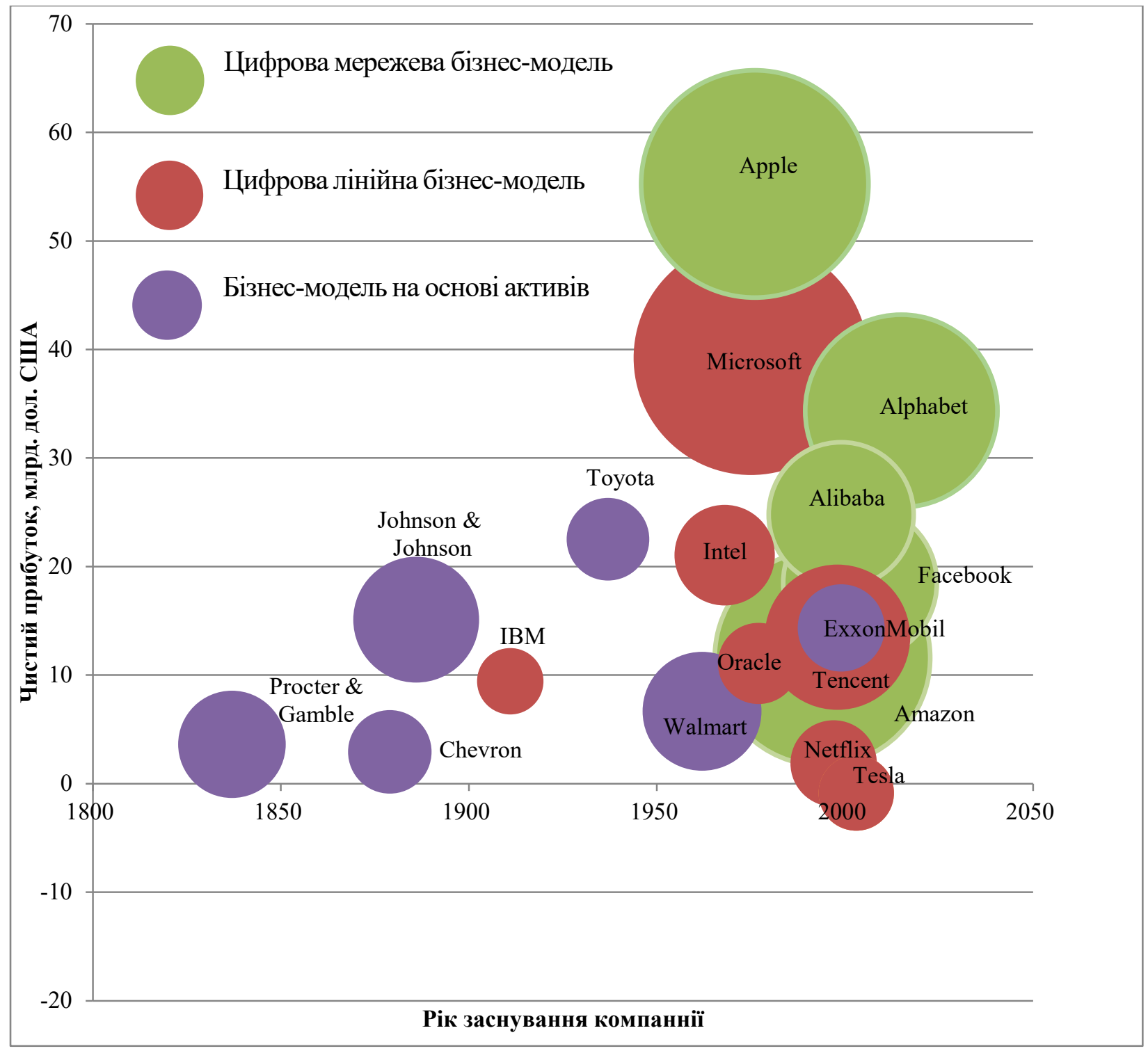

Рис. 2. Ринкова капіталізація і типи бізнес-моделей компаній з різних секторів економіки США (станом на травень 2020 р.) $)^{3}$

Джерело: побудовано авторами за даними [16]

тили податок на прибуток за фрактично нижчою податковою ставкою у порівнянні 3 номінальною. Натомість, для компаній енергетичного сектора (Exxon Mobil Corp. i Chevron Corp.) ефективна податкова ставка значно перевищувала номінальну фредеральну ставку.

Також за даними Європейської комісії податкове навантаження на компанії цифррового бізнесу становить 9,5\%, що більш ніж наполовину нижче тягаря на рівні $23,2 \%$, який несе звичайний бізнес. На додачу до цього в західних країнах внаслідок так званого «ефекту Амазону» один за одним закриваються великі універсальні магазини і інші під- приємства роздрібної торгівлі. Тобто податкове навантаження на цифровий бізнес $€$ легшим в порівнянні 3 податковим тягарем «національного» бізнесу [4]. Це безперечно шкодить принципу конкурентної боротьби «за єдиними правилами» і актуалізує проблему справедливості прямого оподаткування для компаній з різними бізнес-моделями.

Цифррові технології дозволяють розмежувати місце створення вартості і місце ії споживання кінцевим користувачем. Як наслідок, постає питання про те, де виникає прибуток: в країні виготовлення продукту, чи в країні кінцевого споживання.

${ }^{3}$ Площа бульбашки відповідає величині ринкової капіталізації компанії. 
Нині діючі правила оподаткування виходять одночасно і з джерела прибутку, і з місцезнаходження компанії [1; 3; 12$]$.

Модель оподаткування на основі принципу джерела заснована на визначенні місця здійснення господарської діяльності, в результаті якої генерується прибуток (ідея про «місце створення вартості» пов'язана 3 фрізичною присутністю праці або капіталу). Тобто джерело доходності власного капіталу знаходиться в місці фрактичного його фрункціонуваня. Споживчий ринок за таких умов не $є$ драйвером зростання вартості компанії.

Разом $з$ тим, цифрові компанії розвивають свою активну і постійну участь на регіональних ринках, не маючи потреби інвестувати в регіональну інфрраструктуру і операції. Тому прибуток, отриманий тільки від фрактичної присутності в регіоні, не відображатиме стійкої і суттєвої участі на місцевому ринку.
Модель оподаткування на основі принципу місцезнаходження або резидентства компанії ґрунтується на встановленні основного місця діяльності, яке, як правило, визначається за місцем її реєстрації, звідки здійснюється управління господарською діяльністю компанії, або через зв'язок власника компанії і держави (тимчасове проживання, постійне проживання, громадянство). Країни джерела мають переважні права стягувати податку з доходу. Країни місцезнаходження обкладають податком дохід транснаціональних корпорацій, отриманий від інвестицій.

Для визначення того, чи повинна корпорація-нерезидент платити податки в юрисдикції, важливою $€$ концепція постійного представництва. ОЕСР [12] для цифрових компаній пропонує використовувати термін «істотна економічна присутність», що включає в себе як фрізичний, так і цифрровий виміри. Іншими

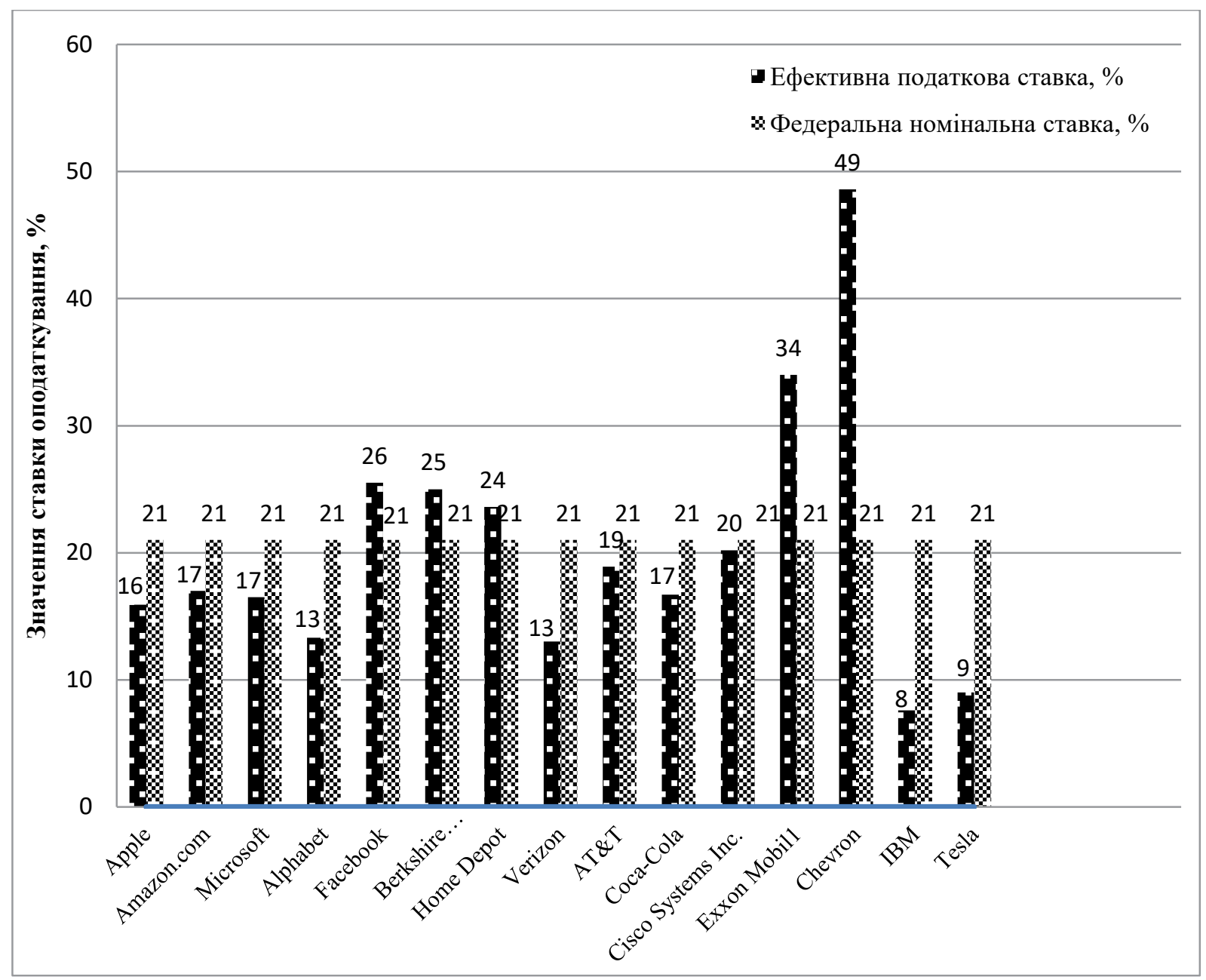

Рис. 3 Порівняння ефективної і номінальної ставок податку на прибуток на прикладі компаній з різних секторів економіки США 
словами, дане поняття означає, чи $є$ іноземна компанія податковим резидентом і чи зобов'язана вона сплачувати належні за місцевим законодавством податки.

Зокрема, пошук критеріїв «цифрової присутності» включає в себе безліч фрактів (насамперед, нематеріальних), що підтверджують стійку взаємодію з певною країною за допомогою цифрових рішень.. Для оподаткування іноземної компанії повинні враховуватися наступні фрактори [2]: наявність національної клієнтської бази (фізичних осіб, які використовують цифрровий продукт або послугу); обсяг цифрового контенту, який створюється національними користувачами (наприклад, відеоролики, створювані користувачами YouTube, TikTok тощо); виставлення рахунків в національній валюті або з використанням національної системи оплати; наявність і обслуговування веб-сайту на мові країни присутності; доставка товарів клієнтам напряму або надання допоміжних послуг, таких як післяпродажне гарантійне обслуговування або ремонт; маркетингові заходи для залучення клієнтів.

ОЕСР пропонує розширити права юрисдикцій, в яких знаходяться споживачі цифрових товарів або послуг з огляду на те, що на сьогодні діє гібридна економічна модель (як поєднання цифрової і традиційної економік) і досить важко відокремити прояви цифрової економіки від традиційної.

Вирішальний вплив на місце розміщення дочірніх компаній чинять ефективні ставки оподаткування корпорацій. Кожен додатковий відсотковий пункт різниці між ставками оподаткування двох країн виражається в зменшенні на 1 відсоток прибутку до оподаткування дочірньої компанії.

Тому особливістю глобальної економіки $€$ податкова конкуренція як прояв суперництва країн за мобільні фрактори виробництва (насамперед, за капітал, меншою мірою - за працю) шляхом зміни податкової політики і впливу на величину податкового тягаря. Однак податкова конкуренція може бути не тільки справедливою (або здоровою), але і нечесною (шкідливою). Шкідлива податкова конкуренція $€$ світовою проблемою. За даними дослідників [18] близько 40 \% прибутку транснаціональних корпорацій щороку переказується до «податкових гаваней». За таких умов втрати з податку на прибуток становлять понад 200 млрд дол.
США на рік, або $10 \%$ світових податкових надходжень

На сьогодні ознаками «шкідливості» податкової системи країни згідно 3 [3; 12] Є вкрай низький рівень податкових ставок; наявність податкових пільг для нерезидентів; надання податкових переваг компаніям за відсутності фрактичної економічної діяльності; визначення бази оподаткування з податку на прибуток за правилами, відмінними від прийнятих міжнародних правил; відсутність прозорості та обміну інформацією з іншими країнами.

Дискусія щодо переосмислення класичних правил розподілу податкової бази податку на прибуток між країною резидентства і країноюджерелом доходів триває. Оскільки серед 137 країн-учасниць проєкту BEPS24, ініційованого ОЕСР і спрямованого на боротьбу 3 розмиванням податкової бази і виведенням прибутку технологічних компаній 3-під оподаткування, відсутній консенсус через політичний вплив технологічних корпорацій. Тому деякі розвинені країни (Франція, Італія, Велика Британія, Канада, Австралія та ін.) вирішили діяти в односторонньому порядку, впроваджуючи податки на цифрові послуги на своїй території.

Висновки. Отже, наше дослідження показало, що трансорормуючи традиційні і створюючи нові бізнес-моделі, циорова економіка ставить нові виклики перед менеджментом компаній, урядами держав, міжнародною спільнотою у галузі фрінансів і оподаткування результатів господарської діяльності. Зокрема, традиційні показники ефективності компаній і принципи фрінансової звітності були розроблені ще в доцифрову епоху і орієнтовані на капіталомістке промислове виробництво на основі переважно лінійної бізнес-моделі. Для сучасних цифрових компаній на основі мережевої бізнес-моделі важливу роль у створенні вартості відіграють дані користувачів і створений ними контент, які потребують особливого підходу до визначення і оподаткування доходів. А цифрова рента, генерована цифровим капіталом, впливає на ідентифрікацію об'єкта оподаткування. Крім того, коли простір фрункціонування фрірми більше не обмежується національними кордонами і місцем розташування її матеріальних активів, стає простіше оптимізувати оподаткування шляхом переведення доходів у податкові юрисдикції з низькими податковими ставками, загострюючи тим самим податкову конкуренцію між державами.

${ }^{4}$ BEPS - Base Erosion and Profit Shifting з англ. Розмивання податкової бази і виведення прибутку з-під оподаткування 


\section{СПИСОК ВИКОРИСТАНИХ ДЖЕРЕЛ:}

1. Bauer G., Bauer Fr., Deborah Sc., Sixt M. Corporate Income Tax Challenges Arising From Digitalised Business Models. March 7. 2019. URL: https://ssrn.com/abstract=3348544 (дата звернення: 12.12.2020).

2. Turina A. The Progressive Policy Shift In The Debate On The International Tax Challenges Of The Digital Economy: A "Pretext" For Overhaul Of The International Tax Regime? Computer Law \& Security Review, 36, 105382. 2020. https://doi.org/10.1016/j.clsr.2019.105382, p1. (дата звернення: 12.12.2020).

3. Cooper M., Quyen T.K. Nguyen Multinational Enterprises And Corporate Tax Planning: A Review Of Literature And Suggestions For A Future Research Agenda. International Business Review. 2020. 29(3). DOI: 10.1016/ j.ibusrev.2020.101692 (дата звернення: 12.12.2020).

4. Morinobu Shigeki. How Should the Digital Economy Be Taxed? URL: https://www.nippon.com/en/in-depth/ d00511/how-should-the-digital-economy-be-taxed.html (дата звернення: 12.12.2020).

5. Okada Yosuke. Addressing the Policy Issues Raised by GAFA and Other Large Tech Firms? URL: https://www.nippon.com/en/in-depth/d00500/addressing-the-policy-issues-raised-by-gafa-and-other-large-techfirms.html (дата звернення: 12.12.2020).

6. Вієцька О.В. Перспективи оподаткування прибутку від реалізації цифррових товарів та послуг в Україні. Економіка промисловості. 2019. № 2. С. 30-37.

7. Кощук Т.В. Шляхи вдосконалення оподаткування цифрових компаній. Фінанси України. 2019. № 10. C. 73-88.

8. Govindarajan V., Rajgopal Sh., Srivastava A. A Blueprint For Digital Companies` Financial Reporting. Harvard Business Review, 2018. August 3. URL: https://hbr.org/2018/08/a-blueprint-for-digital-companies`-financial-reporting (дата звернення: 12.12.2020).

9. Parker G., Van Alstyne M., Jiang X. Platform Ecosystems: How Developers Invert The Firm. MIS Quarterly Vol. 41. No. 1. P. 255-266.

10. Schneider R., Imaia J. User-Based Valuation of Digital Business Models. URL: http://www.realopn.jp/data/ jaros2019-schneider_user-based.pdf (дата звернення: 16.12.2020).

11. OECD (2019). An Introduction to Online Platforms and Their Role in the Digital Transformation, OECD Publishing, Paris. 2019. URL: https://doi.org/10.1787/53e5f593-en. (дата звернення: 16.12.2020).

12. OECD (2018). Digitalisation, business models and value creation, in Tax Challenges Arising from Digitalisation. Interim Report 2018: Inclusive Framework on BEPS, OECD Publishing, Paris. 2018. DOI: https://doi.org/10.1787/9789264293083-4-en (дата звернення: 05.12.2020).

13.Пасквінеллі М. Цифровой неофеодализм: кризис сетевой политики и новая топология ренты. Художественный журнал. № 85. 2012. URL: http://moscowartmagazine.com/issue/12/article/161 (дата звернення: 12.12.2020).

14.Bukh R., Heeks R. Defining, Conceptualising and Measuring the Digital Economy. Global Development Institute working papers. No. 68. URL: https://diodeweb.files.wordpress.com/2017/08/diwkppr68-diode.pdf (дата звернення: 05.11.2020).

15. Govindarajan V., Rajgopal Sh., Srivastava A. Why we need to update Financial Reporting for the digital era. Harvard Business Review, 2018. June 8. URL: https://hbr.org/2018/06/why-we-need-to-update-financial-reportingfor-the-digital-era (дата звернення: 12.12.2020).

16. Financial statements analysis and common stock valuation. Stock Analysis on Net. URL: https://www.stock-analysis-on.net/ (дата звернення: 12.12.2020).

17. The Premier Research Platform for Long Term Investors, Financial Statements Analysis And Common Stock Valuation. Macrotrends. URL: https://www.macrotrends.net/ (дата звернення: 12.12.2020).

18. Tørsløv T., Wier L., Zucman G. The Missing Profits of Nations. URL: https://missingprofits.world/?fbclid=IwA R0kEm6CQRZP3MdEBn1izAOMjp9SBQosAO9fk9IG6aJG0X4Rv1_89CfNuKo (дата звернення: 12.12.2020).

\section{REFERENCES:}

1. Bauer G., Bauer Fr., Deborah Sc., Sixt M. (2019). Corporate Income Tax Challenges Arising From Digitalised Business Models. March 7. Available at: https://ssrn.com/abstract=3348544 (accessed 12 December 2020).

2. Turina, A. (2020). The Progressive Policy Shift In The Debate On The International Tax Challenges Of The Digital Economy: A "Pretext" For Overhaul Of The International Tax Regime? Computer Law \& Security Review, 36, 105382. Available at: https://doi.org/10.1016/j.clsr.2019.105382, p1.

3. Cooper M., Quyen T.K. (2020). Nguyen Multinational Enterprises And Corporate Tax Planning: A Review Of Literature And Suggestions For A Future Research Agenda. International Business Review, 29(3). DOI: 10.1016/ j.ibusrev.2020.101692 (accessed 12 December 2020). 
4. Morinobu Shigeki. How Should the Digital Economy Be Taxed? Available at: https://www.nippon.com/en/ in-depth/d00511/how-should-the-digital-economy-be-taxed.html (accessed 12 December 2020).

5. Okada Yosuke. Addressing the Policy Issues Raised by GAFA and Other Large Tech Firms? Available at: https://www.nippon.com/en/in-depth/d00500/addressing-the-policy-issues-raised-by-gafa-and-other-large-techfirms.html (accessed 12 December 2020).

6. Viietska O. (2019). Perspektyvy opodatkuvannia prybutku vid realizatsii tsyfrovykh tovariv ta posluh v Ukraini [Prospects of profit taxation from digital products realization and services in Ukraine]. Economy of industry, vol. 2, pp. 30-37. (in Ukrainian)

7. Koshcuk T. (2019). Shliakhy vdoskonalennia opodatkuvannia tsyfrovykh kompanii [Ways to improve digital companies taxation]. Finances of Ukraine, vol. 10, pp. 73-88.

8. Govindarajan V., Rajgopal Sh., Srivastava A. (2018). A Blueprint For Digital Companies` Financial Reporting. Harvard Business Review, August 3. URL: https://hbr.org/2018/08/a-blueprint-for-digital-companies`-financial-reporting (accessed 12 December 2020).

9. Parker G., Van Alstyne M., Jiang X. Platform Ecosystems: How Developers Invert The Firm. MIS Quarterly, vol. 41, no. 1, p. 255-266.

10. Schneider R., Imaia J. User-Based Valuation of Digital Business Models. Available at: http://www.realopn.jp/ data/jaros2019-schneider_user-based.pdf (accessed 16 December 2020).

11. OECD (2019). An Introduction to Online Platforms and Their Role in the Digital Transformation. Paris: OECD Publishing. Available at: https://doi.org/10.1787/53e5f593-en (accessed 16 June 2020).

12. OECD (2018). "Digitalisation, business models and value creation", in Tax Challenges Arising from Digitalisation - Interim Report 2018: Inclusive Framework on BEPS. Paris: OECD Publishing. Available at: https://doi.org/10.1787/9789264293083- 4-en (accessed 05 June 2020).

13. Paskvinelli M. (2012). Tsifrovoi neofeodalizm: krizis setevoi politiki i novaya topologiya renty [Digital neo-feudalism: the crisis of network policy and the new rent topology]. Journal of Art, vol. 85. Available at: http://moscowartmagazine.com/issue/12/article/161 (accessed 12 December 2020). (in Russian)

14. Bukh R., Heeks R. Defining, Conceptualising and Measuring the Digital Economy. Global Development Institute working papers, no. 68. URL: https://diodeweb.files.wordpress.com/2017/08/diwkppr68-diode.pdf (accessed: 05 June 2020).

15. Govindarajan V., Rajgopal Sh., Srivastava A. (2018). Why we need to update Financial Reporting for the digital era. Harvard Business Review (electronic journal). Available at: https://hbr.org/2018/06/why-we-need-to-updatefinancial-reporting-for-the-digital-era (accessed: 12 July 2020).

16. Financial statements analysis and common stock valuation. Stock Analysis on Net. URL: https://www.stock-analysis-on.net/ (accessed 12 December 2020).

17. The Premier Research Platform for Long Term Investors, Financial Statements Analysis And Common Stock Valuation. Macrotrends. URL: https://www.macrotrends.net/ (accessed 12 December 2020).

18. Tørsløv T., Wier L., Zucman G. The Missing Profits of Nations. Available at: https://missingprofits. world/?fbclid=IwAR0kEm6CQRZP3MdEBn1izAOMjp9SBQosAO9fk9IG6aJG0X4Rv1_89CfNuKo (accessed 12 December 2020). 